\title{
TREATMENT OF NEPHROSIS WITH PITUITARY ADRENOCORTICOTROPHIN ${ }^{2}$
}

\author{
By JOHN A. LUETSCHER, JR., QUENTIN B. DEMING, AND BEN B. JOHNSON WITH \\ THE ASSISTANCE OF JULIA HARVEY, WILLIAM LEW, AND LEE J. POO \\ (From the Department of Medicine, Stanford University School of Medicine, San Francisco, Cal.)
}

(Submitted for publication May 31, 1951; accepted September 18, 1951)

\section{INTRODUCTION}

The administration of pituitary adrenocorticotrophin (ACTH) to patients with nephrosis has been reported to initiate diuresis in a large proportion of cases (1-6). Since this diuresis may occur either during or after the administration of ACTH, it is not clear how such a diuresis is related to the secretions of the adrenal cortex. Renal function is usually markedly improved (7), but the relationship in time of such improvement with diuresis is not definitely established. In order to visualize the timing of some changes in renal and adrenal function, together with the shifts in fluids, electrolytes, and proteins, a continuous series of measurements has been made during treatment of nephrosis with ACTH.

\section{?}

\section{SUBJECTS AND METHODS}

Fourteen patients with nephrosis have been treated with ACTH. Patients varied from two to 50 years of age. All presented the edema, proteinuria, hypoproteinemia, and hypercholesterolemia characteristic of the syndrome. No patient had a systolic blood pressure above $145 \mathrm{~mm}$. $\mathrm{Hg}$ before treatment. Only one patient had an elevated serum creatinine level (3.0 mg.\% in case 12). Quantitative examination of the urinary sediment showed no abnormality in cases 3,7 , and 8 ; the presence of some casts and epithelial cells containing fat, and 1 to 5 million red blood cells per 24 hours in cases $1,2,4,5,10,11$, and 12 ; and a heavy sediment containing many casts, epithelial cells loaded with fat, and 15 to 120 million red blood cells per 24 hours in cases $6,9,13$, and 14. In case 9, the nephrotic syndrome was associated with signs of disseminated lupus erythematosus. In case 11 , there was a severe hemolytic anemia which responded fairly well to cortisone and remained relatively inactive during treatment with ACTH. In cases $3,6,7,11$, and 14 , cortisone had been administered without a satisfactory diuresis.

Controls, experimental procedure, and follow-up have been described in a previous report (8). Total serum protein and albumin were determined by micro-Kjeldahl

1 This investigation was supported by a research grant from the National Heart Institute, U. S. Public Health Service. analysis for nitrogen. The separation of albumin with sodium sulfate, used in the present work, has been previously (9) found to give a value for serum albumin which is approximately $0.7 \mathrm{gm} . / 100 \mathrm{cc}$. greater than that obtained by electrophoresis. Because of the error introduced in the electrophoretic technique by the obvious variations in lipemia, the salting-out method was selected as more appropriate for comparing results before and after treatment. Protein in urine was measured in ShevskyStafford tubes after centrifugation in a constant-speed centrifuge and corrected for the small variations in temperature.

"Creatinine" was determined without preliminary separation and thus includes other chromogens. Since multiple daily venepunctures were avoided in order to reduce blood loss, the effect of possible diurnal variation in the plasma "creatinine" was not taken into account except when short-term clearances were measured.

ACTH was obtained from Armour and Co. as a lyophilized powder. Daily dosage was given by intramuscular injection in four equal parts at intervals of six hours. Several different lots of ACTH were used in the course of the study, but there was no evidence that failure was due to absence of adrenal cortical response, with the possible exception of case 12 , in which neither a satisfactory eosinopenia nor a significant rise in 17-ketosteroids was observed during administration of ACTH.

\section{RESULTS}

The effects of administration of ACTH on diuresis and on edema varied in degree and in time of appearance (Tables I and II). Four general types of response were noted:

Group 1. Diuresis with complete elimination of edema during administration of ACTH.

Group 2. Diuresis beginning during administration of ACTH, completed after end of therapy.

Group 3. Diuresis beginning after discontinuing administration of ACTH.

Group 4. No effective diuresis.

Although these differences in time of diuresis are not clearly related to the duration of treatment, it is possible that all patients would have eliminated their edema if treatment had been continued for 
a longer period. Patients in groups 3 and 4, however, showed no signs of such improvement during nine to 14 days of treatment.

Group 1. Two patients, one with heavy edema and one with slight edema, showed oliguria and reduced sodium excretion for the first three days of ACTH administration. Subsequently increasing diuresis and sodium excretion resulted in complete elimination of edema by the end of treatment on the 11th and 13th days (Figure 1, Tables I and II).

Group 2. Four patients, two of whom received a second course of treatment with similar results, showed more or less oliguria for the first one to five days of ACTH administration (Table II). The depression of urine volume occurred even when sodium excretion before treatment was too low to be significantly reduced by ACTH. Subsequent diuresis reached a maximum on the fifth to

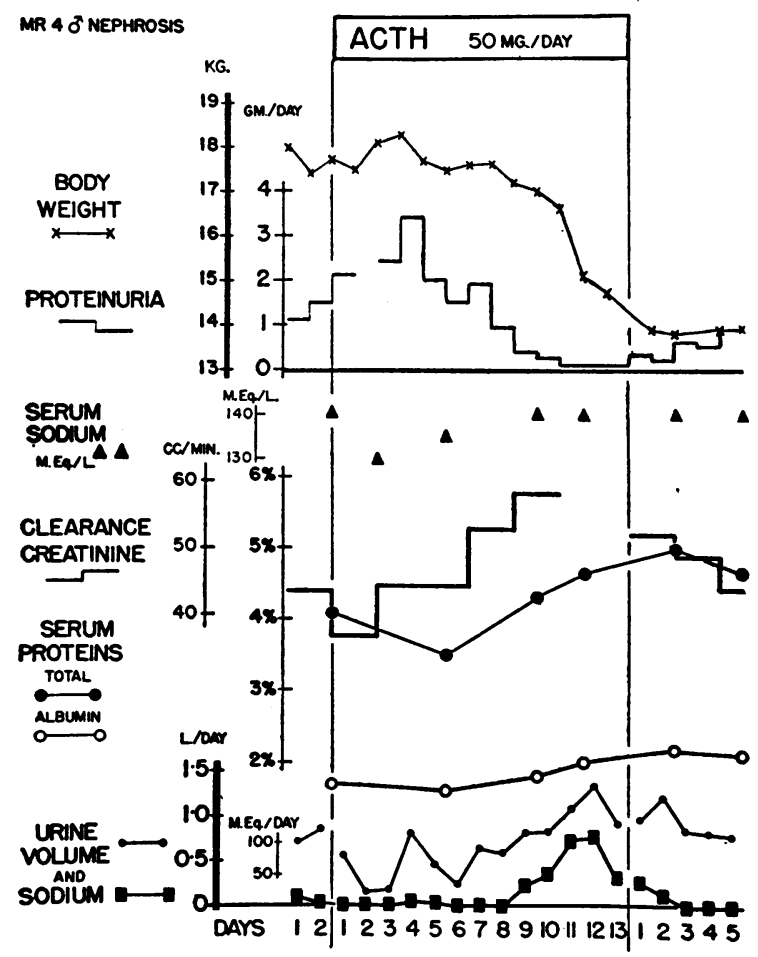

Fig. 1. Diuresis with Elimination of Edema and Reduction of Proteinuria to Normal during AdminisTRATION OF ACTH (CASE 2)

Aggravation of all abnormalities during first few days of treatment was followed by improvement during the second week on ACTH. There was a rapid return toward control levels when treatment was stopped. Edema reappeared one month later.

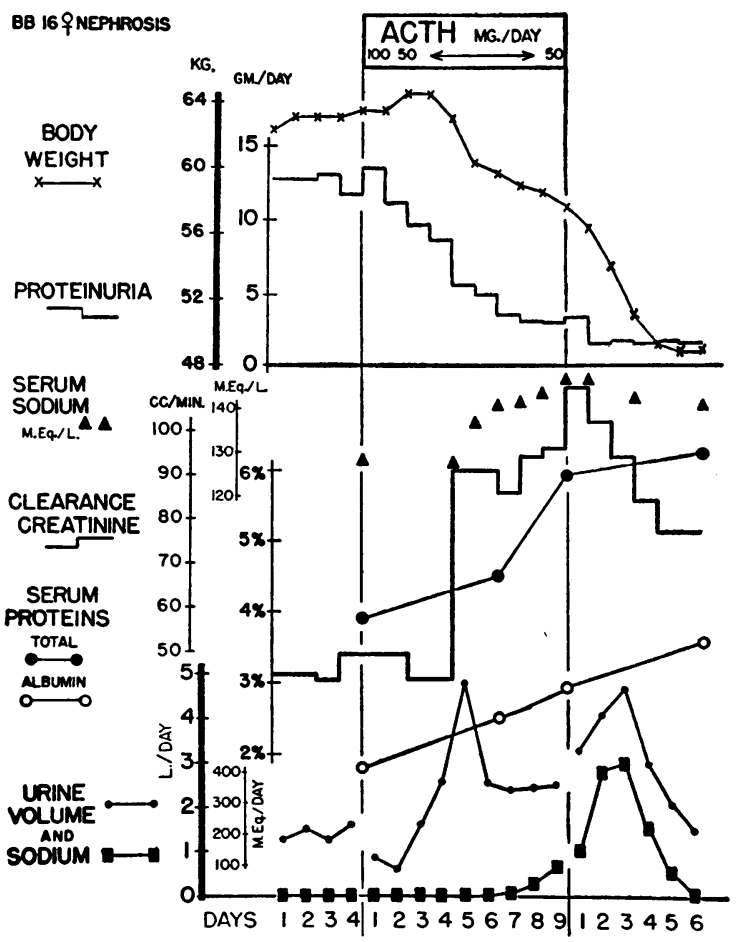

Fig. 2. DiUREsis DURING AND AFTER Administration OF ACTH (CASE 3a)

After the fourth day of ACTH, there were sharp increases in creatinine clearance and in urine volume, followed by rising serum sodium and finally by a rise in urinary sodium. Diuresis increased when ACTH was withheld. Proteinuria remained low after treatment. Serum proteins reached a peak of $6.3 \%$ (albumin $3.9 \%$ ) two weeks after treatment.

tenth day of treatment. In two cases, diuresis and elimination of edema at the end of ACTH administration were proceeding at a steady or increasing rate, which increased sharply when ACTH was withheld (Figure 2). In these cases, diuresis might well have gone on to complete relief of edema if treatment had been continued. In the other two cases, however, the rate of diuresis had reached a maximum and was falling at the end of ACTH administration, leaving considerable edema. A second peak of weight loss and of sodium excretion appeared on the first to fourth day after the end of therapy (Figure 3 ).

Group 3. Four patients showed oliguria and sodium retention, as in the other patients, but effective diuresis did not occur during the second week of treatment (Table II). The serum sodium concentration remained low. Sodium excretion 
remained well below the intake of sodium. Observations at the end of nine to 14 days of ACTH gave no promise of impending diuresis (Figure 4).

When administration of ACTH was stopped, there was a large increase in urine volume, beginning within 24 hours of the last injection. The serum sodium concentration rose rapidly, and large amounts of sodium were excreted in the urine. Elimination of edema followed in five to nine days after the end of ACTH administration.

Group 4. Four patients had no effective diuresis during or after treatment. This group included three patients with considerably reduced renal function due to chronic glomerulonephritis. The fourth patient (case 13) developed signs of acute infection when ACTH was withdrawn, followed by delayed and sluggish diuresis.

Serum sodium concentration was frequently below the average normal level before administration of ACTH (Table II). There was no obvious re- lationship between the degree of restriction of sodium intake and the individual levels of serum sodium before treatment. When ACTH was administered, the serum sodium concentration usually fell (average -5 m.eq./L) with the initial reduction of urine volume and gain in weight (Table II, Figures 1 and 4). Restriction of sodium intake may have exaggerated the fall in sodium concentration. After ten days of treatment, the serum sodium concentration was 140 m.eq./L or higher in nine of the 16 observations. Groups 1 and 2 were consistently normal (average 142 m.eq./L, Table II) at the end of treatment. In group 3 , the concentration of sodium fell to very low levels (Table II) and was still far below normal (average $128 \mathrm{~m} . e q . / \mathrm{L}$ ) at the end of treatment. Group 4 showed a variable pattern. No specific symptoms referable to the lowered serum sodium concentration were noted.

The fall in the serum sodium concentration in

TABLE I

\begin{tabular}{|c|c|c|c|c|c|c|c|c|c|}
\hline \multirow{2}{*}{$\begin{array}{l}\text { Case } \\
\text { No. }\end{array}$} & \multirow{2}{*}{$\begin{array}{c}\text { Age } \\
\text { (yrs.) }\end{array}$} & \multirow{2}{*}{$\begin{array}{l}\text { Duration } \\
\text { of edema } \\
\text { (months) }\end{array}$} & \multicolumn{2}{|c|}{ ACTH } & \multicolumn{2}{|c|}{ Body weight } & \multicolumn{3}{|c|}{ Proteinuria* } \\
\hline & & & Days & $\begin{array}{l}\text { Total } \\
\text { (me.) }\end{array}$ & $\underset{(k g .)}{\text { After }} \mathbf{A}$ & $\begin{array}{l}\text { Weight } \\
\text { change } \\
\text { (kg.) }\end{array}$ & $\begin{array}{c}\text { Control } \\
\text { average } \\
(g m . / \text { day })\end{array}$ & $\underset{(\mathrm{gm} . / \text { day })}{\text { Range on } R}$ & $\begin{array}{c}\text { Range post } \mathrm{P} \\
(\mathrm{gm} . / \text { day })\end{array}$ \\
\hline
\end{tabular}

I. Diuresis complete

\begin{tabular}{l|l|l|l|l|l|l|l|l|l|l|l}
\hline 1 & 4 & 3 & 13 & 650 & 13.7 & -4.1 & 1.1 & $3.4(4)-0.08(11)$ & $0.21(2)-1.08(7)$ \\
2 & 7 & 2 & 11 & 550 & 27.6 & -2.4 & 2.4 & $3.0(3)-0.08(10)$ & $0.12(2)-0.07(6)$ \\
\hline
\end{tabular}

II. Diuresis started during treatment,

\begin{tabular}{l|r|r|r|r|r|r|r|l|l}
\hline $3 \mathrm{a}$ & 16 & 2 & 9 & 500 & 48.9 & -14.3 & 12.5 & $13.4(1)-2.9(9)$ & $3.3(1)-1.0(26)$ \\
$3 \mathrm{~b}$ & 16 & 8 & 10 & 600 & 55.0 & -4.1 & 6.0 & $11.5(2)-0.3(10)$ & $0.5(2)-0.1(7)$ \\
4 & 3 & 24 & 10 & 800 & 15.7 & -2.9 & 1.9 & $1.6(1)-0.4(10)$ & $1.1(1)-0.2(2)$ \\
$5 \mathrm{a}$ & 2 & 5 & 13 & 650 & 13.8 & -1.0 & 1.6 & $1.3(7)-5.0(13)$ & $4.8(8+)-0.2(20)$ \\
$5 \mathrm{~b}$ & 3 & 10 & 12 & 1,030 & 13.1 & -3.3 & 2.7 & $5.4(4)-0.7(11)$ & $0.5(3)-0.2(6)$ \\
6 & 22 & 11 & 10 & 500 & 63.4 & -6.1 & 14.7 & $15.0(1)-29.2(6)$ & $23.0(3)-15.2(5)$ \\
\hline
\end{tabular}

III. Diuresis prima-

\begin{tabular}{r|r|r|r|r|r|r|r|l|l}
\hline 7 & 50 & 4 & 9 & 550 & 49.5 & -10.5 & 3.3 & $6.1(6)-3.1(8)$ & $1.2(3)-2.5 \pm(7)$ \\
8 & 2 & 8 & 11 & 550 & 11.1 & -5.6 & 1.6 & $-1.11(10)$ & $0.11(1)-0.02(8)$ \\
9 & 39 & 6 & 14 & 1,500 & 55.8 & -4.6 & 6.0 & $7.1(3)-16.0(13)$ & $10.6(3)-4.7(11)$ \\
10 & 3 & 4 & 10 & 250 & 16.2 & -7.3 & 5.5 & $3.2(3)-9.1(7)$ & $10.3(5 \dagger)-1.5(11)$ \\
\hline
\end{tabular}

IV. Diuresis

\begin{tabular}{|c|c|c|c|c|c|c|c|c|c|}
\hline $\begin{array}{l}11 \\
12 \\
13 \\
14\end{array}$ & $\begin{array}{r}34 \\
39 \\
3 \\
35\end{array}$ & $\begin{array}{r}36 \\
7 \\
2\end{array}$ & $\begin{array}{l}10 \\
10 \\
12\end{array}$ & $\begin{array}{r}1,000 \\
525 \\
640\end{array}$ & $\begin{array}{l}51.1 \\
97.7 \\
78.1\end{array}$ & $\begin{array}{l}-0.4 \\
-1.8 \\
-1.4\end{array}$ & $\begin{array}{r}6.2 \\
11.5 \\
16.0\end{array}$ & $\begin{array}{l}8.9(3)-4.3(8) \\
\text { Unchanged } \\
13.7(1)-21.3(12)\end{array}$ & $\begin{array}{l}4.4(1)-6.3(4) \\
\text { Unchanged } \\
23.2(5)-16.4(8)\end{array}$ \\
\hline
\end{tabular}

* Number in parenthesis indicates day of treatment or after treatment when maximum or minimum was observed. $\dagger$ Intercurrent infection. 
the early days of treatment was usually associated with increases in body weight and edema and with a fall in urine volume, suggesting a dilution of the extracellular fluid. The return of the serum sodium concentration to higher levels with increasing urine volume at the beginning of diuresis supported this impression. However, some obvious discrepancies suggest that other factors play a role. Exchanges of sodium between cells and extracellular fluid are by no means excluded.

Increased excretion of sodium in the urine appeared at a variable level of serum sodium, generally approaching normal levels (Figures 1-4).

Endogenous "creatinine" clearance increased regularly after the first few days of treatment (Table II). The average increase was $63 \%$ of the control level. Improvement often continued for some days after administration of ACTH was stopped. Then there was usually a gradual decline in clearance, but case 3 (Table II) still showed a virtually normal "creatinine" clearance when she returned six months after the first course of treatment because of recurrence of edema.

No consistent difference in the changes in "creatinine" clearance between the four groups was evident to account for the difference in time of diuresis.

The relationship between the clearances of "creatinine" and inulin has not been systematically measured. A few observations (Table IV) indicated that the general pattern of changes in the two clearances could be parallel. Barnett and his co-workers (7), using a more specific creatinine method, have noted much greater rises in inulin clearance than in creatinine clearance in children with nephrosis. In some of the cases reported here, the changes in glomerular filtration rate may thus have been even greater than the observed changes in "creatinine" clearance.

Sodium-retaining activity of the corticoid fraction of urine was equivalent to 3.4 to $9.6 \gamma$ of desoxycorticosterone per 20 minutes of urine

TABLE I (Continued)

\begin{tabular}{|c|c|c|c|c|c|c|c|c|c|}
\hline \multicolumn{3}{|c|}{ Serum proteins } & \multicolumn{3}{|c|}{ Serum albumin } & \multicolumn{3}{|c|}{ Serum cholesterol } & \multirow{2}{*}{$\begin{array}{l}\text { Case } \\
\text { No. }\end{array}$} \\
\hline $\begin{array}{c}\text { Control } \\
\text { (em./100 cc.) }\end{array}$ & $\underset{(\mathrm{gm.} / 100 \mathrm{cc} .)}{\text { End B }}$ & $\underset{(\mathrm{gm} . / 100 \mathrm{cc.})}{\text { Maximum }}$ & $\begin{array}{c}\text { Control } \\
(\mathrm{gm} . / 100 \text { cc. })\end{array}$ & $\underset{(\mathrm{gm} . / 100 \mathrm{cc} .)}{\text { End R }}$ & $\underset{(\mathrm{gm} . / 100 \mathrm{cc.})}{\text { Maximum }}$ & $\begin{array}{c}\text { Control } \\
\text { (mg./100 cc.) }\end{array}$ & $\underset{(m g . / 100 \mathrm{cc} .)}{\text { End B }}$ & $\underset{(\operatorname{mg} . / 100 \text { cc. })}{\text { Minimum }}$ & \\
\hline
\end{tabular}

during treatment

\begin{tabular}{l|l|l|l|l|l|l|l|l|l|l|l|l}
\hline 4.1 & 4.6 & 5.0 & 1.7 & 2.0 & 2.2 & 770 & & 485 & 1 \\
4.2 & 5.7 & 5.7 & 2.0 & 3.6 & 3.8 & 980 & 680 & 620 & 2 \\
\hline
\end{tabular}

completed after end of treatment

\begin{tabular}{r|l|l|l|l|l|l|l|l|l}
\hline 3.9 & 6.2 & 6.3 & 1.8 & 2.9 & 3.9 & 607 & 877 & 550 & $3 \mathrm{a}$ \\
4.5 & 6.1 & 6.7 & 2.2 & 3.4 & 4.6 & 634 & 448 & 280 & $3 \mathrm{~b}$ \\
3.4 & 4.1 & 5.2 & 1.3 & 2.0 & 2.7 & 737 & 680 & 514 & 4 \\
3.7 & 4.6 & 4.4 & 1.5 & 2.0 & 2.0 & 910 & $\frac{7}{52}$ & 725 & $5 \mathrm{a}$ \\
3.5 & 4.7 & 5.9 & 1.7 & 2.6 & 3.0 & 1120 & 850 & 542 & $5 \mathrm{~b}$ \\
3.7 & 4.3 & 5.0 & 1.8 & 2.0 & 2.4 & 1100 & 877 & 1020 & 6 \\
\hline
\end{tabular}

rily post-treatment

\begin{tabular}{l|l|l|l|l|l|l|l|l|l}
\hline 4.0 & 4.1 & $5.0 \ddagger$ & 1.6 & 2.0 & $2.7 \ddagger$ & 670 & 607 & 412 & 7 \\
3.1 & 2.7 & 4.1 & 0.5 & 1.2 & 2.0 & $\frac{7}{3}$ & 390 & 8 \\
5.6 & 4.9 & 5.6 & 2.4 & 2.2 & 2.4 & 300 & 417 & 370 & 9 \\
3.9 & 4.6 & 4.6 & 1.2 & 2.5 & 2.5 & 1100 & 980 & 530 & 10 \\
\hline
\end{tabular}

ineffectual

\begin{tabular}{l|l|l|l|l|l|l|l|l|l|l|l}
\hline 4.0 & 4.6 & 4.2 & 1.9 & 2.8 & 2.0 & 440 & & 455 & 11 \\
2.9 & 3.3 & 3.2 & 1.7 & 1.8 & 1.8 & - & & - \\
4.4 & 3.6 & 3.6 & 1.5 & 1.2 & 1.6 & 2.1 & 1100 & 1070 & 804 & 14 \\
3.6 & 3.6 & &
\end{tabular}

$\ddagger$ Follow-up six weeks after discharge: Proteinuria $0.1 \mathrm{gm} . /$ day; serum proteins 6.0 , albumin $4.2 \mathrm{gm} . / 100 \mathrm{cc}$. 
TABLE II

\begin{tabular}{|c|c|c|c|c|c|c|c|c|c|}
\hline \multirow{3}{*}{$\begin{array}{l}\text { Case } \\
\text { No. }\end{array}$} & \multicolumn{2}{|c|}{ Edema } & \multirow{3}{*}{$\underset{\begin{array}{c}\text { Sodium } \\
\text { intake } \\
(m . e q . / \text { day })\end{array}}{ }$} & \multicolumn{4}{|c|}{ Sodium output in urine } & \multicolumn{2}{|r|}{ Urine } \\
\hline & \multirow{2}{*}{ Control } & \multirow{2}{*}{$\underset{\text { post } \mathbf{R}}{\text { Minimum }}$} & & \multirow{2}{*}{$\begin{array}{c}\text { Control } \\
\text { average } \\
\text { (m.eq./day) }\end{array}$} & \multicolumn{2}{|c|}{ During treatment } & \multirow{2}{*}{$\underset{(m . e q . / \text { day })}{\text { After }} \mathbf{R}$} & \multirow{2}{*}{$\begin{array}{l}\text { Control } \\
\text { average } \\
\text { (cc./day) }\end{array}$} & During \\
\hline & & & & & $\underset{(m . e q . / \text { day })}{\text { Minimum }}$ & $\underset{(m . e q . / \text { day })}{\text { Maximum }}$ & & & $\underset{(c c . / d a y)}{\text { Minimum }}$ \\
\hline
\end{tabular}

I. Diuresis complete

\begin{tabular}{l|l|l|l|l|l|l|l|l|l|l|l}
\hline 1 & $4+$ & 0 & 17. & 9.7 & $1.2(3)^{*}$ & $111(12)$ & $40(1)$ & 720 & $150(2)$ \\
2 & $1+$ & 0 & 17. & 17.0 & $0.9(3)$ & $37(3)$ & $20(3)$ & 640 & $345(3)$ \\
\hline
\end{tabular}

II. Diuresis started during treatment,

\begin{tabular}{l|l|l|l|l|l|l|l|r|r}
\hline $3 \mathrm{a}$ & $4+$ & 0 & 17. & 0.7 & $0.9(2)$ & $96(9)$ & $421(3)$ & 1410 & $610(2)$ \\
$3 \mathrm{~b}$ & $3+$ & 0 & 17. & $52.0 \dagger$ & $1.0(2)$ & $92(10)$ & $164(2)$ & 2100 & $1280(1)$ \\
4 & $3,+$ & 0 & 22. & 0.7 & $2.0(1)$ & $80(10)$ & $165(1)$ & 200 & $165(1)$ \\
$5 \mathrm{a}$ & $3+$ & 0 & 5. & 0.4 & $0.1(3)$ & $40(10)$ & $33(4)$ & 185 & $87(3)$ \\
$5 \mathrm{~b}$ & $3+$ & 0 & 17. & 0.8 & $0.3(5)$ & $95(10)$ & $200(1)$ & 210 & $123(3)$ \\
6 & $2+$ & \pm & 34. & $39.4 \dagger$ & $19.1(1)$ & $149(6)$ & $107(1)$ & 1510 & $1230(1)$ \\
\hline
\end{tabular}

III. Diuresis prima-

\begin{tabular}{|c|c|c|c|c|c|c|c|c|c|}
\hline $\begin{array}{r}7 \\
8 \\
9 \\
10\end{array}$ & $\begin{array}{l}4+ \\
4+ \\
3+ \\
4+\end{array}$ & $\begin{array}{l}0 \\
0 \\
0 \\
0\end{array}$ & $\begin{array}{l}17 . \\
5 . \\
51 . \\
9-17\end{array}$ & $\begin{array}{r}1.6 \\
0.3 \\
34.0 \\
0.3\end{array}$ & $\begin{array}{l}0.9(4) \\
0.1(4) \\
5.6(2) \\
0.1(2)\end{array}$ & $\begin{array}{r}2.5(6) \\
1.1(11) \\
34.5(12) \\
1.0(10)\end{array}$ & $\begin{array}{r}517(4) \\
99(7) \\
98(7) \\
327(5)\end{array}$ & $\begin{array}{r}760 \\
140 \\
1750 \\
480\end{array}$ & $\begin{array}{l}450(1) \\
\overline{770(4)} \\
240(5)\end{array}$ \\
\hline \multicolumn{10}{|c|}{ IV. Diuresi } \\
\hline $\begin{array}{l}11 \\
12 \\
13 \\
14\end{array}$ & $\begin{array}{l}3+ \\
4+ \\
4+ \\
4+\end{array}$ & $\begin{array}{l}3+ \\
4+ \\
4+ \\
3+\end{array}$ & $\frac{17}{17}$ & $\begin{array}{r}\frac{1.8}{0.5} \\
11.4\end{array}$ & $\begin{array}{l}0.6(5) \\
\bar{Z} \\
0.2(3)\end{array}$ & $\begin{array}{l}2.0(10) \\
1 . \overline{3(9) \S} \\
1.0(5)\end{array}$ & $\begin{array}{c}18.0(4) \\
121.0(11) \\
24.6(5)\end{array}$ & $\begin{array}{r}800 \\
900 \\
235 \\
1150\end{array}$ & $\begin{array}{l}390(1) \\
560(4) \\
\overline{360(1)}\end{array}$ \\
\hline
\end{tabular}

* Number in parenthesis indicates day of observation.

† Sodium intake above $\mathbf{5 0}$ m.eq./day on previous days.

(Table III). The average of these determinations was $5.2 \gamma$, compared with a normal average of $1.5 \gamma$ (normal range 0 to $3.4 \gamma$ ). The restriction of sodium intake may have accounted in part for the abnormally high output of sodium-retaining corticoids in some of the patients, but the data in case 10 suggest that wide variations in dietary sodium did not affect the assay significantly. In the other cases, changes in sodium-retaining activity occurred under treatment with ACTH without any change in the sodium intake.

In two cases, considerable increases in sodiumretaining activity were noted on the second and third days on ACTH, coincident with the decrease in sodium excretion.

In groups 1 and 2 , five of the six series of assays showed a distinct fall in sodium-retaining activity during or after administration of ACTH. In the sixth (case 3a), the level of activity had fallen after treatment with cortisone and albumin. No significant change in activity was noted when ACTH was given, but when a second course of ACTH (case 3b) was given six months later because of a recurrence of edema, the sodium-retaining activity responded as in the other cases. In case 5, a more rapid diuresis and a sharper fall in sodium-retaining activity were noted on the second course of ACTH (case 5b).

In contrast to the effects of cortisone, which usually resulted in a diuresis and a fall in sodiumretaining activity after the end of treatment (8), three patients who lost much of their edema during ACTH administration showed a disappearance of the excessive sodium-retaining activity on the ninth to 11th days of ACTH therapy (Table III, cases $1,3 b, 5 b)$. In these patients, there was a rise in sodium-retaining activity on the first or second day after the end of ACTH administration. 
TABLE II (Continued)

\begin{tabular}{|c|c|c|c|c|c|c|c|c|c|}
\hline \multicolumn{2}{|l|}{ volume } & \multicolumn{4}{|c|}{ Serum sodium concentration } & \multicolumn{3}{|c|}{ Creatinine clearance } & \multirow{3}{*}{$\begin{array}{l}\text { Case } \\
\text { No. }\end{array}$} \\
\hline treatment & \multirow{2}{*}{$\underset{(c c . / \text { day })}{\text { After }} \mathbf{R}$} & \multirow{2}{*}{$\underset{(m . e q . / L)}{\text { Control }}$} & \multicolumn{2}{|c|}{ During treatment } & \multirow{2}{*}{$\underset{(m . e q . / L)}{\underset{\text { maximum }}{\text { After }}}$} & \multirow{2}{*}{$\begin{array}{c}\text { Control } \\
\text { average } \\
\left(c c . / \text { min. }^{\prime} /\right. \\
1.73 \mathrm{m.2})\end{array}$} & \multirow{2}{*}{ 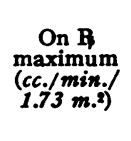 } & \multirow{2}{*}{$\underset{\substack{\text { maximum } \\
\left(c c . / \min _{\text {. }} /\right.}}{\text { Af. }}$} & \\
\hline$\underset{(\text { cc./day })}{\text { Maximum }}$ & & & $\underset{(m . e q . / L)}{\text { Minimum }}$ & $\underset{(m . e q . / L)}{\text { Maximum }}$ & & & & & \\
\hline \multicolumn{10}{|c|}{ during treatment } \\
\hline $\begin{array}{l}1340(12) \\
1160(9)\end{array}$ & $\begin{array}{l}1230(2) \\
1180(2)\end{array}$ & $\begin{array}{l}140.5 \\
142.0\end{array}$ & $\begin{array}{l}130.0(3) \\
140.0(9)\end{array}$ & $\begin{array}{l}140.0(10) \\
141.5(2)\end{array}$ & $\begin{array}{l}140.0(3) \\
141.5(6)\end{array}$ & $\begin{array}{l}44 \\
64\end{array}$ & $\begin{array}{l}58(10) \\
80(9)\end{array}$ & $\begin{array}{l}52(1) \\
81(1)\end{array}$ & $\begin{array}{l}1 \\
2\end{array}$ \\
\hline \multicolumn{10}{|c|}{ completed after end of treatment } \\
\hline $\begin{array}{c}4810(5) \\
4160(10) \\
686(10) \\
275(8) \\
1350(10) \\
3450(6)\end{array}$ & $\begin{array}{r}4675(3) \\
4200(2) \\
1270(1) \\
440(6) \\
2150(1) \\
2320(3)\end{array}$ & $\begin{array}{l}128.0 \\
143.0 \\
138.0 \\
135.0 \\
132.5 \\
141.0\end{array}$ & $\begin{array}{l}127.0(4) \\
141.0(3) \\
138.0(2) \\
127.5(5) \\
127.5(4) \\
139.0(6)\end{array}$ & $\begin{array}{l}146.0(9) \\
144.5(6) \\
145.0(9) \\
138.0(11) \\
141.5(11) \\
142.0(4)\end{array}$ & $\begin{array}{l}146.0(1) \\
143.0(21) \\
143.0(2) \\
140.0(4) \\
142.5(2) \\
137.0(3)\end{array}$ & $\begin{array}{c}46 \ddagger \\
102 \\
39 \\
40 \\
52 \\
64 \ddagger\end{array}$ & $\begin{array}{c}97(9) \\
123(8) \\
78(10) \\
68(12) \\
63(10) \\
87(10)\end{array}$ & $\begin{array}{c}113(1) \\
107(2) \\
86(4) \\
82(2) \\
73(4) \S \\
86(1)\end{array}$ & $\begin{array}{l}3 \mathrm{a} \\
3 \mathrm{~b} \\
4 \\
5 \mathrm{a} \\
5 \mathrm{~b} \\
6\end{array}$ \\
\hline
\end{tabular}

rily post-treatment

\begin{tabular}{|c|c|c|c|c|c|c|c|c|c|}
\hline $\begin{array}{r}1450(9) \\
500(9) \\
2400(7) \\
1415(9)\end{array}$ & $\begin{array}{l}5380(4) \\
1230(6) \\
4320(3) \\
3800(5)\end{array}$ & $\begin{array}{l}135.0 \\
130.0 \\
131.0 \\
116.0\end{array}$ & $\begin{array}{l}125.5(5) \\
120.0(7) \\
117.0(14) \\
114.5(2)\end{array}$ & $\begin{array}{l}127.0(3) \\
131.5(10) \\
123.0(7) \\
132.0(10)\end{array}$ & $\begin{array}{l}137.0(8) \\
144.0(13) \\
135.5(9) \\
140.5(4)\end{array}$ & $\begin{array}{l}25 \\
29 \\
45 \\
60\end{array}$ & $\begin{array}{l}32(7) \\
32(7) \\
68(13) \\
96(10)\end{array}$ & $\begin{array}{l}36(4) \\
37(5) \\
70(1) \\
97(11) \S\end{array}$ & $\begin{array}{r}7 \\
8 \\
9 \\
10\end{array}$ \\
\hline \multicolumn{10}{|l|}{ ineffectual } \\
\hline $\begin{array}{r}1080(3) \\
910(3) \\
455(9) \\
680(5)\end{array}$ & $\begin{array}{l}2150(1) \\
2015(6) \\
1045(11) \\
2485(1)\end{array}$ & $\begin{array}{l}138.0 \\
138.0 \\
138.0 \\
137.5\end{array}$ & $\begin{array}{l}132.0(6) \\
137.0(3) \\
\overline{123.0(11)}\end{array}$ & $\begin{array}{l}133.5(8) \\
140.0(8) \\
141.0(11) \\
134.0(2)\end{array}$ & $\begin{array}{c}139.0(4) \\
139.0(5) \\
\overline{138.0(9)}\end{array}$ & $\begin{array}{c}22 \ddagger \\
\text { Serum } \\
\text { Serum } \\
27 \ddagger\end{array}$ & $\begin{array}{c}\mid 25(\mathrm{p}) \| \\
\text { creatinine }= \\
\text { creatinine }= \\
\mid 40(8)\end{array}$ & $\begin{array}{l}43(p) \| \\
\mathrm{mg} \% \\
8 \mathrm{mg} \% \\
39(1)\end{array}$ & $\begin{array}{l}11 \\
12 \\
13 \\
14\end{array}$ \\
\hline
\end{tabular}

$\ddagger$ Modified by recent administration of cortisone.

Intercurrent infection.

$\|(p)=$ pooled specimen.

In group 3, the time of diuresis and of fall in sodium-retaining activity resembled the events after successful use of cortisone, when maximal diuresis and fall of sodium-retaining activity to low levels was noted on the fourth or a later day after the end of treatment (Table III, cases 7, 10).

Serum potassium concentration was not greatly affected by treatment. In an effort to avoid a sharp rise in serum potassium during treatment, similar to that occasionally observed during treatment of nephrosis with cortisone $(8,10)$, a reduction in potassium intake by the elimination of foods very high in potassium was made in the present study. Perhaps as a result of the smaller potassium intake, or perhaps because of other differences in the actions of ACTH, the trend of the present group was toward a lower serum potassium during treatment. In five patients, the concentra- tion of potassium fell below 4 m.eq./L in the serum, the lowest level being 3.1 m.eq./L. An increased potassium intake prevented further fall in the concentration of potassium in the serum. ${ }^{2}$ The serum potassium level returned promptly to normal when treatment was stopped. The level of potassium in the serum is apparently regulated with difficulty during treatment, and should be carefully followed.

Proteinuria was sometimes increased above control levels during treatment with ACTH. Subsequently, it was greatly reduced in ten of the 15 courses of ACTH in 14 patients (Table I). In

\footnotetext{
2 In one patient observed after the completion of this report, the serum potassium fell from 4.0 to $1.9 \mathrm{~m} . e q . / \mathrm{L}$ in two days of rapid diuresis during ACTH administration. Intensive replacement of potassium and withdrawal of ACTH were necessary to control the sharp fall in serum potassium concentration.
} 
four patients, the urinary protein reached a minimum of $100 \mathrm{mg}$. or less per day. In general, reduction of proteinuria occurred at about the same time as diuresis. Although diuresis might occur without reduction of proteinuria, proteinuria was not observed to fall without diuresis. Thus, in groups 1 and 2 , seven of the eight cases showed reduction of proteinuria during treatment, although a minimum was usually reached after the end of treatment. In group 3, only one patient showed a reduction in proteinuria during treatment, while in the other three patients, the reduction of proteinuria, like diuresis, occurred after the end of treatment. Proteinuria was unchanged in group 4.

Concentration of serum proteins and albumin were significantly increased in 11 of the 12 cases in which diuresis was observed (Table I). In four cases, the levels of total protein and albumin approached normal. The average changes in groups 1, 2, and 3 were: total protein increased

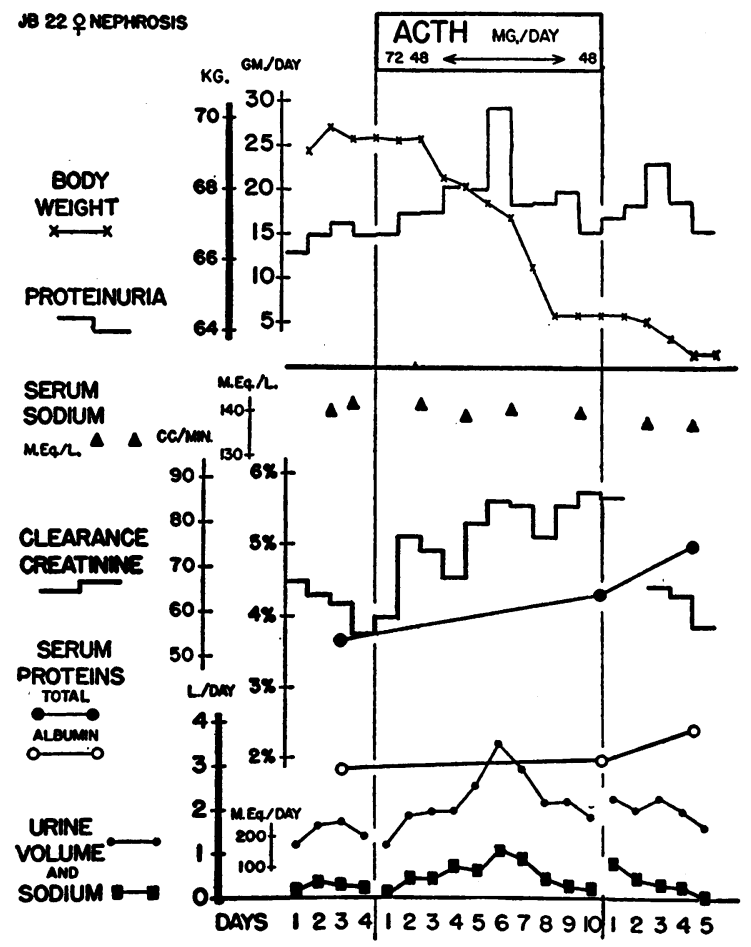

Fig. 3. Partial Diuresis during Administration of ACTH (CASE 6)

A second peak of sodium excretion and weight loss occurred after ACTH was withheld. Proteinuria was not significantly affected, but serum protein levels were increased.

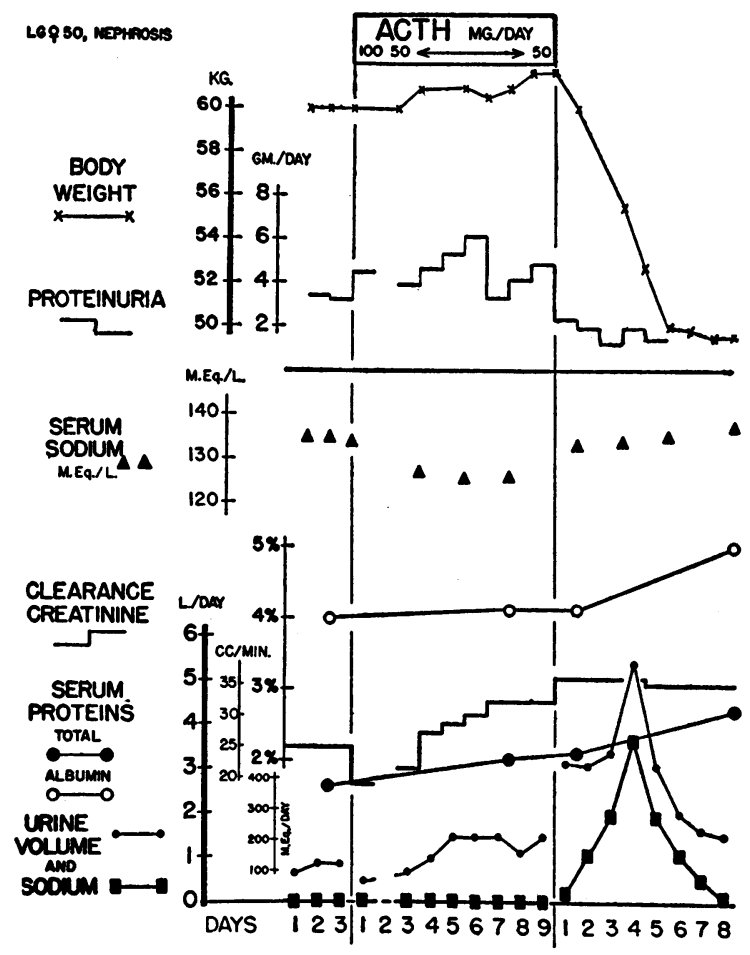

Fig. 4. Diuresis after End of Administration of ACTH (CASE 7)

No clinical evidence of improvement appeared during treatment, although creatinine clearance and serum proteins showed slight increases. After the end of treatment, a brisk diuresis ushered in a remission which has continued for ten months, with normal blood proteins and no abnormality of the urine.

from 4.0 to $5.3 \mathrm{gm} . / 100 \mathrm{cc}$. and albumin increased from 1.6 to $2.8 \mathrm{gm} . / 100 \mathrm{cc}$.

It is of some interest that considerable increases in total protein or albumin concentration may occur while proteinuria continues at a steady or increased rate. A part of the increased concentration may be due to the shrinkage of extracellular fluid volume during diuresis (e.g., case 6), but in cases 11,12 , and 13 , the improvement in albumin or protein concentration without diuresis or decrease in proteinuria suggests an increased production or release of proteins into the plasma.

Microscopic examination of the urinary sediment showed a disappearance of abnormal forms after treatment in cases 1,2 , and 4 . These patients excreted red blood cells ( 1 to 4 million/24 hours), epithelial cells containing fat, and a variable number of hyaline and granular casts before treatment. After treatment, these abnormalities were consist- 
TABLE III

Sodium-retaining activity of urinary corticoid fraction*

(expressed in equivalents in micrograms of desoxycorticosterone per 20 minutes of urine)

\begin{tabular}{|c|c|c|c|c|c|c|}
\hline Case No. & Day of urine collection & Clinical status & $\begin{array}{l}\text { Sodium- } \\
\text { retaining } \\
\text { activity } \\
(\gamma)\end{array}$ & $\begin{array}{c}\text { Urine } \\
\text { volume } \\
\text { (cc./day) }\end{array}$ & $\underset{\substack{\text { Sodium } \\
\text { (m.eq./day) }}}{\underset{n}{\text { Unine }}}$ & $\underset{\substack{\text { sodium } \\
(m . e q . / L)}}{\underset{m}{\text { Sodium }}}$ \\
\hline 1 & $\begin{array}{l}\text { Control } \\
\text { On ACTH day } 3 \\
\text { On ACTH day } 11 \\
\text { After ACTH day } 1\end{array}$ & $\begin{array}{l}\text { Heavy edema } \\
\text { Edema worse } \\
\text { Lost } 2.6 \mathrm{~kg} \text {. } \\
\text { No edema }\end{array}$ & $\begin{array}{l}4.4 \\
7.2 \\
0.7 \\
0.8\end{array}$ & $\begin{array}{r}853 \\
184 \\
1085 \\
975\end{array}$ & $\begin{array}{l}5.0 \\
1.2 \\
97.0 \\
40\end{array}$ & $\begin{array}{l}140 \\
130 \\
140 \\
140\end{array}$ \\
\hline $3 \mathbf{a}$ & $\begin{array}{l}\text { Control } \\
\text { After cortisone and al- } \\
\text { bumin } \\
\text { On ACTH day } 7 \\
\text { After ACTH day } 3\end{array}$ & $\begin{array}{l}\text { Heavy edema } \\
\text { Little change } \\
\text { Diuresis water } \\
\text { Peak of diuresis }\end{array}$ & $\begin{array}{l}4.3 \\
2.4 \\
2.5 \\
2.7\end{array}$ & $\begin{array}{r}405 \\
1230 \\
\\
2405 \\
4675\end{array}$ & $\begin{array}{r}0.4 \\
0.6 \\
11.3 \\
421 .\end{array}$ & $\begin{array}{l}133 \\
130 \\
141 \\
142\end{array}$ \\
\hline $3 b$ & $\begin{array}{l}\text { Control } \\
\text { On ACTH day } 2 \\
\text { On ACTH day } 9 \\
\text { After ACTH day } 2\end{array}$ & $\begin{array}{l}\text { Recurrence of edema } \\
\text { Unchanged } \\
\text { Lost } 1.4 \mathrm{~kg} . \\
\text { End of diuresis }\end{array}$ & $\begin{array}{l}3.4 \\
5.2 \\
0.5 \\
3.6\end{array}$ & $\begin{array}{l}2030 \\
2060 \\
3150 \\
4200\end{array}$ & $\begin{array}{c}50 . \\
1.0 \\
49 . \\
164 .\end{array}$ & $\begin{array}{l}143 \\
141 \\
144 \\
142\end{array}$ \\
\hline 4 & $\begin{array}{l}\text { Control } \\
\text { After ACTH day } 2\end{array}$ & $\begin{array}{l}\text { Heavy edema } \\
\text { Lost } 2.4 \mathrm{~kg} .\end{array}$ & $\begin{array}{l}3.8 \\
2.6\end{array}$ & $\begin{array}{r}115 \\
1025\end{array}$ & $\begin{array}{l}0.5 \\
113 .\end{array}$ & $\begin{array}{l}138 \\
143\end{array}$ \\
\hline $5 a$ & $\begin{array}{l}\text { Control } \\
\text { After diuretic } \\
\text { On ACTH day } 5 \\
\text { On ACTH day } 10 \\
\text { After ACTH day } 1 \\
\text { After ACTH day } 4\end{array}$ & $\begin{array}{l}\text { Edema } 3+ \\
\text { Unchanged } \\
\text { Edema worse } \\
\text { Lost } 0.3 \mathrm{~kg} . \\
\text { Lost } 0.6 \mathrm{~kg} \text {. total } \\
\text { No visible edema }\end{array}$ & $\begin{array}{l}5.2 \\
7.3 \\
8.9 \\
4.1 \\
5.7 \\
3.1\end{array}$ & $\begin{array}{l}144 \\
170 \\
152 \\
263 \\
240 \\
282\end{array}$ & $\begin{array}{r}1.9 \\
0.3 \\
0.1 \\
40.2 \\
2.2 \\
33.3\end{array}$ & $\begin{array}{l}138 \\
135 \\
128 \\
137 \\
138 \\
140\end{array}$ \\
\hline $5 b$ & $\begin{array}{l}\text { Control } \\
\text { On ACTH day } 5 \\
\text { On ACTH day } 10 \\
\text { After ACTH day } 1\end{array}$ & $\begin{array}{l}\text { Edema } 3+ \\
\text { Edema worse } \\
\text { Lost } 1.4 \mathrm{~kg} . \\
\text { Peak of diuresis }\end{array}$ & $\begin{array}{l}5.6 \\
5.0 \\
0 \dagger \\
3.3\end{array}$ & $\begin{array}{r}257 \\
190 \\
1350 \\
2150\end{array}$ & $\begin{array}{l}1.3 \\
0.3 \\
95 . \\
200 .\end{array}$ & $\begin{array}{l}133 \\
129 \\
140 \\
142\end{array}$ \\
\hline 7 & $\begin{array}{l}\text { Control } \\
\text { After ACTH day } 4\end{array}$ & $\begin{array}{l}\text { Heavy edema } \\
\text { Peak of diuresis }\end{array}$ & $\begin{array}{l}5.5 \\
0 f\end{array}$ & $\begin{array}{r}823 \\
5380\end{array}$ & $\begin{array}{l}2.0 \\
517 .\end{array}$ & $\begin{array}{l}134 \\
134\end{array}$ \\
\hline \multirow[t]{3}{*}{10} & $\begin{array}{l}\text { Regular diet } \\
\text { Paracentesis } \\
\text { Na intake 9m.eq. }\end{array}$ & $\begin{array}{l}\text { Heavy edema } \\
\text { Edema same }\end{array}$ & $\begin{array}{l}9.6 \\
9.5\end{array}$ & $\begin{array}{l}208 \\
850\end{array}$ & $\begin{array}{l}0.2 \\
0.5\end{array}$ & $\begin{array}{l}135 \\
116\end{array}$ \\
\hline & $\begin{array}{l}\text { On ACTH day } 2 \\
\mathrm{Na} \text { added to diet } \\
\text { On ACTH day } 8\end{array}$ & $\begin{array}{l}\text { Edema same } \\
\text { Edema same }\end{array}$ & $\begin{array}{l}7.7 \\
6.6\end{array}$ & $\begin{array}{r}680 \\
1415\end{array}$ & $\begin{array}{l}0.1 \\
0.5\end{array}$ & 125 \\
\hline & After ACTH day 4 & Rapid diuresis & 1.1 & 2630 & 316. & 140 \\
\hline
\end{tabular}

* See Addendum, p. 1541

† Caused increased sodium excretion in rats.

ently absent. In three other cases, no abnormality was noted before or after treatment. Eight other patients showed no change in number or type of abnormal cells or casts observed before treatment.

Serum cholesterol was frequently decreased during treatment (Table I) and returned gradually toward normal after treatment when improvement continued.

Hematocrit was insignificantly affected during or after treatment. An occasional striking improvement is masked in the averages by declines in other cases, usually small children. The repeated drawing of blood for chemical analysis may have affected these results.

Erythrocyte sedimentation rate was reduced after treatment only in cases 3 and 6 . In the other patients, the rapid sedimentation was unaffected.

White blood cells were increased in number during administration of ACTH from a control average of $8,600 / \mathrm{c} . \mathrm{mm}$. to an average peak of $21,600 /$ c.mm. during treatment. Counts returned to normal within a few days after treatment.

Eosinophilic leukocytes were found in the blood in numbers between 100 and 300/c.mm. in eight 
TABLE IV

Comparison of clearances of creatinine and inulin during and after diuresis in case $3 b$

\begin{tabular}{|c|c|c|c|c|}
\hline \multirow[b]{2}{*}{ Day of test } & \multirow[b]{2}{*}{$\begin{array}{l}\text { Clinical } \\
\text { status }\end{array}$} & \multicolumn{3}{|c|}{ Clearance } \\
\hline & & $\begin{array}{r}\underset{(\operatorname{anulin})^{*}}{(c c .)}\end{array}$ & $\begin{array}{c}\text { Creatinine } \\
\text { (a.m.) }\end{array}$ & $\begin{array}{l}\text { Creatinine } \\
\text { (24-hour) } \\
\text { (m.) }\end{array}$ \\
\hline Control & $\begin{array}{c}\text { Edema } \\
3+\end{array}$ & 112 & 111 & 102 \\
\hline АСТН day 7 & $\begin{array}{l}\text { Begin- } \\
\text { ning di- } \\
\text { uresis }\end{array}$ & 133 & 121 & 115 \\
\hline ACTH day 10 & $\begin{array}{l}\text { Increas- } \\
\text { ing di- } \\
\text { uresis }\end{array}$ & 132 & 119 & 122 \\
\hline $\begin{array}{l}3 \text { days after last } \\
\text { dose of ACTH }\end{array}$ & $\begin{array}{l}\text { End of } \\
\text { diuresis }\end{array}$ & 121 & 116 & 96 \\
\hline
\end{tabular}

* (a.m.) indicates the average clearance during three periods of 30 minutes each on the morning of the day noted.

of the patients before treatment. In five of the patients, there were 325 to 2850 eosinophiles/ c.mm. Two patients had counts below $100 /$ c.mm. During treatment eosinophiles fell to between 0 and 11 cells $/ \mathrm{c} . \mathrm{mm}$. in 11 patients. In terms of percent of counts before treatment, eosinophiles were reduced to less than $10 \%$ of the control level in 13 of 15 courses of treatment. Cases 4 and 12 showed reductions to 30 and $66 \%$, respectively, of the control levels.

It was of some interest that the number of eosinophiles tended to fall sharply and then to rise slowly in some patients who showed a diuresis during the later days of therapy. Some observations on urinary 17-ketosteroid excretion by two of these patients, as well as a few reported observations by other workers $(6,11)$, do not support the suggestion that there might be a decline of adrenal secretion at this time.

Blood pressure was increased in ten patients during treatment, essentially unchanged in three, and slightly decreased in one patient. The average blood pressure in these patients was $120 / 80$ before treatment and 132/85 at the end of administration of ACTH. Either systolic or diastolic pressure might be affected. Maxima observed were 170 systolic and 110 diastolic. In ten patients, blood pressure during the five days after the end of treatment fell below the pre-treatment level by an average of $15 \mathrm{~mm}$. $\mathrm{Hg}$. In the rest of the group, blood pressure was not affected or it returned gradually to control levels, remaining elevated above the control level for as long as a week in one patient.

Duration of effects. Three of the ten patients (cases $2,4,7$ ) who lost all edema during or after the first course of administration of ACTH are in remission three to ten months later, with diminished proteinuria and freedom from edema.

Seven patients have had a recurrence of edema, beginning from one to four months after treatment. In four of these patients (cases 1, 5, 8 and 10), a severe respiratory infection was followed by increased proteinuria and appearance of edema of slight to moderate degree. Three other patients have had a gradual return of edema, attributed by the patient to posture (sitting at a desk in school), to exposure to sun, or to no evident reason. In most of these cases, the edema has been quite moderate in extent, sometimes being present only during or after a respiratory infection. Appetite and general condition have remained excellent.

A second course of ACTH has been given to three of these patients (cases $3,5,9$ ) because of persistent edema and gradual deterioration of appetite, activity, and psychological outlook. The response to treatment was similar to that after the first course. A greater reduction in proteinuria was noted on the second trial of ACTH in case $3 \mathrm{~b}$, while edema was more promptly and completely eliminated in case $5 \mathrm{~b}$. Insufficient data are available for an exact comparison of the second course of ACTH in case 9, but the clinical response was similar in all respects.

The three patients who received a second course of ACTH are free of edema. Case 9 has been treated too recently to allow any evaluation. In cases 3 and 5, reduced proteinuria and freedom from edema have continued for two and five months, respectively, after treatment.

\section{DISCUSSION}

The mechanism by which improvement occurs during or after treatment of nephrosis with ACTH is complex, but certain results of treatment are clear.

The initial effect of ACTH is often an aggravation of the clinical picture of nephrosis. Edema and proteinuria are usually increased, urine volume falls, and there may be a temporary reduc- 
tion of "creatinine" clearance. Abnormalities of the urinary sediment may be even more evident in the highly concentrated urine. These changes occur at a time when the symptoms of rheumatic or "collagen" disease would be clearing. In case 9, for example, the general signs of lupus erythematosus disseminatus were promptly improved by $\mathrm{ACTH}$, while the evidences of the renal lesion were unchanged or aggravated.

After some days of treatment, signs of improvement appear. In about.half of the cases, profuse diuresis and progressive loss of edema are seen during treatment. Several factors which may affect diuresis are modified at this time. These include the clearances of "creatinine" and of inulin, the serum sodium concentration, and the sodium-retaining activity of the corticoid fraction of urine.

There is a considerable increase in the clearance of "creatinine" in most of these patients, as has been previously observed (7). This improvement usually reaches a peak near the end of treatment, and subsequently declines. A variable degree of the gain in "creatinine" clearance is maintained.

The changes are larger in magnitude and more persistent than those observed in patients without renal disease treated with ACTH $(12,13)$. There is no clear correlation between any given level of clearance and clinical improvement.

A subnormal concentration of sodium in the serum of an edematous patient, reflecting an excess of water over sodium in extracellular fluid, occurs commonly in patients with nephrosis. During the first days of treatment with $\mathrm{ACTH}$, this situation may be aggravated. The adrenal 11oxysteroids, excreted in increasing quantities under the influence of $\mathrm{ACTH}(6,11)$, have an appreciable diuretic action under similar conditions (14). This action could account for the diuresis of water and the subsequent rise in the serum sodium concentration, which usually precede an effective diuresis.

Measurement of the sodium-retaining activity of the corticoid fractions of the urines of this group of patients with nephrosis shows greater than normal activity before treatment. This abnormally high sodium-retaining activity may be increased initially when ACTH is given, and then falls when diuresis occurs. Similar observations in patients treated with cortisone show a reduced sodium-retaining activity during the diuresis which often follows after cortisone administration. The hypothesis that cortisone suppresses the output of an active sodium-retaining hormone has been offered as a possible explanation. The fall in urinary sodium-retaining activity which accompanies the diuresis during the second week of ACTH administration can not be satisfactorily explained in this way, since studies of other adrenal secretions show a continued or increasing level of adrenal activity at this time. Further studies are necessary to evaluate hypotheses concerning changes in metabolism (15), competitive interactions, and variations in responsiveness of the renal tubules (2).

When reduction in proteinuria and improvement in urinary sediment occur, these changes appear at approximately the same time as the diuresis. It seems probable that all of these events are mediated by closely related factors, as yet ill-defined.

The improvement in the concentrations of albumin and of total proteins in the serum is generally greatest if both a diuresis and a reduction in proteinuria occur. Reduction of proteinuria does not seem to be a necessary factor for improvement in the concentration of serum proteins, however. In several cases, a virtual cessation of proteinuria was followed by a very disappointing improvement in serum protein levels. As in other forms of treatment, proteinuria and hypoproteinemia are no obstacle to diuresis, while maximum improvement in serum proteins occurs after the end of the diuresis $(9,16)$.

Moderate increases in plasma volume have been observed in children with nephrosis during treatment with ACTH (7). Significant changes were associated with proportional reduction in the hematocrit. The hematocrit was usually unchanged or moderately increased in adult patients in the present study. It seems unlikely that any large increase in plasma volume occurred, unless this was masked by a simultaneous and proportional increase in red blood cell volume. Further studies of this possibility are indicated.

The effect of these changes on the ultimate course of the disease remains to be evaluated by follow-up for a longer period of time. In the meanwhile, the clinical manifestations of the disease have been greatly improved. Most of these 
patients are leading an essentially normal life except for continued restriction of sodium intake.

A comparison of the effects of ACTH and cortisone shows many points of similarity. A few differences appear to be consistent. The administration of ACTH is followed by diuresis in a higher proportion of cases than in a similar group treated with cortisone. Diuresis may appear during treatment with $\mathrm{ACTH}$, while it rarely appears until after the end of cortisone administration. Reduction of proteinuria below the control level occurs commonly during ACTH treatment, while such improvement is noted less frequently after the withdrawal of cortisone. The fall in serum cholesterol is much more striking after administration of ACTH. Increases in blood pressure are more impressive during ACTH than during cortisone treatment. In the dosage used, ACTH appears to be more effective than cortisone in inducing an immediate improvement in a larger proportion of cases, but the difference in frequency of response is not so great as might be inferred from scattered reports of a few cases, some of whom were inadequately treated with cortisone. In larger groups of unselected patients, the frequency of diuresis is only moderately less after cortisone than after treatment with ACTH (8, 10). Further study of cortisone, ACTH, and related compounds and of different plans of treatment is indicated.

\section{SUM MARY}

When ACTH was administered for nine to 14 days to 14 patients with nephrosis, the following results were noted:

(1) Almost all patients retained water and gained weight. There was reduction of urinary sodium excretion and increased proteinuria. In this group of patients on a small sodium intake, the concentration of sodium in the serum fell during this phase, which lasted from one to 14 days.

(2) In six cases, increasing diuresis appeared on the second to sixth day of ACTH treatment, and was followed by a rise in the serum sodium concentration and gradually increasing excretion of sodium in the urine. This diuresis resulted in the elimination of most of the edema. A second increase in diuresis and loss of edema occurred after treatment was stopped.

(3) In four cases, no effective diuresis ap- peared during nine to 14 days of treatment, but there was complete elimination of edema by a rapid diuresis beginning immediately after the end of administration of ACTH.

(4) In four cases, no significant clinical improvement was observed.

(5) Proteinuria was reduced in eight of the ten patients who lost their edema. In four cases, the excretion of protein in the urine fell to normal levels.

(6) All abnormalities of the urinary sediment disappeared in three cases.

(7) There were increases in the concentrations of protein and albumin in the serum, apparently related in part to diuresis and to reduction in proteinuria, but not always explicable on these bases.

(8) The abnormally high concentration of cholesterol in the serum was usually decreased.

(9) There was increased clearance of endogenous "creatinine" during treatment. After treatment, "creatinine" clearance usually decreased, but some improvement above control levels was maintained.

(10) The abnormally high sodium-retaining activity of the urinary corticoids decreased at the time of diuresis during or after treatment.

(11) The blood pressure was variably increased during treatment, but usually fell below control levels after the end of treatment.

(12) The concentration of potassium in the serum varied either above or below normal in different patients. These variations were difficult to predict, but, once determined, could probably be minimized by appropriate changes in potassium intake.

(13) The clinical improvement induced by ACTH was generally fully maintained for a few months, after which a recurrence of the nephrotic syndrome might follow a minor infection or might appear without obvious cause. Remissions have persisted for many months.

(14) A second course of treatment with ACTH was effective in the treatment of recurrent edema after the first course of cortisone or ACTH.

\section{CONCLUSIONS}

1. The administration of ACTH is followed by elimination of edema and by improvement in the other abnormalities of nephrosis in a large proportion of the cases treated. 
2. Certain physiological changes are observed regularly to precede or accompany the elimination of edema. The most important are increasing renal clearance of "creatinine," increasing urine flow, increasing serum sodium concentration, and decreasing sodium-retaining activity of the urinary corticoids. No one of these physiological measurements appears to be the sole regulator of diuresis. Elimination of edema seems to be the result of a favorable combination of the important factors, which may occur during or immediately after the administration of ACTH.

4. The parallel changes in edema and proteinuria, both increasing in the first days of ACTH treatment, and both usually decreasing simultaneously whether during or after treatment, suggest that these abnormalities are regulated by closely related mechanisms. The concentration of the plasma proteins seems to be affected secondarily.

5. The modification of the most important physiological manifestations of the nephrotic syndrome by the adrenal cortical steroids is again demonstrated. The exact role of these steroids in aggravating or improving the renal disturbance remains uncertain.

\section{ACKNOWLEDGMENT}

The authors wish to express their gratitude to the visiting and resident staffs of Stanford University Hospitals for referral of patients and for assistance in their care; to the nurses of the medical and pediatric wards; to the dieticians for the special diets; to Armour Laboratories for ACTH; to Dr. Edward Henderson of Schering Corp. for desoxycorticosterone; and to Dr. F. S. Greenspan for assistance with determinations of 17 -ketosteroids.

\section{ADDENDUM}

Since this report was prepared, some observations show that the solvent in which the standard DCA and the unknown are dissolved has an appreciable sodium-retaining effect in the method of bioassay used, although it was thought to be inert on the basis of previous controls with a less sensitive method. This systematic error does not affect values about $5 \boldsymbol{\gamma}$, but adds an increasing blank to less active materials. No change in interpretation appears necessary, since correction of the error would result in more impressive changes of the type described.

\section{REFERENCES}

1. Farnsworth, E. B., Metabolic changes associated with the administration of adrenocorticotrophin in the nephrotic syndrome. Proc. Soc. Exper. Biol. \& Med., 1950, 74, 60.

2. Thorn, G. W., Merrill, J. P., Smith, S., III, Roche, M., and Frawley, T. F., Clinical studies with ACTH and cortisone in renal disease. Arch. Int. Med., 1950, 86, 319.

3. Frenkel, M., Groen, J., and Hellinga, G., Observations in a patient with chronic nephritis with nephrotic syndrome during administration of corticotropic hormone. J. Clin. Endocrinol., 1950, 10, 799.

4. Barnett, H. L., McNamara, H., McCrory, W., Forman, C., Rapoport, M., Michie, A., and Barbero, G., Effects of ACTH and cortisone on the nephrotic syndrome. Am. J. Dis. Child., 1950, 80, 519.

5. Riley, C. M., Nephrotic syndrome: effect of adrenocorticotrophic hormone. Pediatrics, 1951, 7, 457.

6. Spector, S., and Matthews, L. W., Effect of pituitary ACTH in children with nephrosis. Am. J. Dis. Child., 1950, 80, 886.

7. Barnett, H. L., Forman, C. W., McNamara, H., McCrory, W. W., Rapoport, M., Michie, A. J., and Barbero, G., The effect of adrenocorticotrophic hormone on children with the nephrotic syndrome. II. Physiologic observations on discrete kidney functions and plasma volume. J. Clin. Invest., 1951, 30, 227.

8. Luetscher, J. A., Jr., and Deming, Q. B., Treatment of nephrosis with cortisone. J. Clin. Invest., 1950, 29, 1576.

9. Luetscher, J. A., Jr., Hall, A. D., and Kremer, V. L., Treatment of nephrosis with concentrated human serum albumin. I. Effects on the proteins of body fluids. J. Clin. Invest., 1949, 28, 700.

10. Keith, N. M., Power, M. H., Daugherty, G. W., and Keith, H. M., Some effects of cortisone on the metabolic disturbance associated with glomerulonephritis with edema. J. Lab. \& Clin. Med., 1950, 36, 843.

11. Farnsworth, E. B., and Dupee, C., Further studies on the effects of ACTH in the nephrotic syndrome, in Proceedings of the Second Clinical ACTH Conference, edited by Mote, J. R. The Blakiston Co., New York, 1951, Vol. II, Chap. 11, p. 149.

12. Ingbar, S. H., Relman, A. S., Burrows, B. A., Kass, E. H., Sisson, J. H., and Burnett, C. H., Changes in normal renal function resulting from $\mathrm{ACTH}$ and cortisone. J. Clin. Invest., 1950, 29, 824.

13. Kendrick, A. B., Schoenberger, J. A., Dyniewicz, J. M., Grinelli, L. J., and Keeton, R. W., Studies of renal function in patients receiving $A C T H$ and cortisone. J. Lab. \& Clin. Med., 1950, 36, 844.

14. Gaunt, R., Birnie, J. H., and Eversole, W. J., Adrenal cortex and water metabolism. Physiol. Rev., 1949, 29, 281.

15. Pincus, G., Regulation of adrenal cortical secretion, in Transactions of the First Conference on the Adrenal Cortex (Nov. 1949). Josiah Macy, Jr. Foundation, New York, 1950.

16. Luetscher, J. A., Jr., Hall, A. D., and Kremer, V. L., Treatment of nephrosis with concentrated human serum albumin. II. Effects on renal function and on excretion of water and some electrolytes. J. Clin. Invest., 1950, 29, 896. 